\title{
PERANCANGAN GAME EDUKASI SEJARAH KEMERDEKAAN INDONESIA MENGGUNAKAN APLIKASI CONSTRUCT 2 BERBASIS ANDROID
}

\author{
Lidya Dias ${ }^{1}$, Jhon Enstein ${ }^{2}$, Gerlan Apriandy Manu ${ }^{3}$ \\ 1,2,3 Universitas Citra Bangsa, Propinsi Nusa Tenggara Timur \\ Ilidyadias210@gmail.com, 2enstein_j17@yahoo.com, ${ }^{3}$ gerlan.manu@gmail.com
}

\begin{abstract}
ABSTRAK
Perkembangan teknologi informasi pada saat ini meningkat dengan pesat. Pemanfaatan teknologi informasi tidak hanya pada sektor bisnis saja, tetapi juga pada sektor publik. Salah satu instansi sektor publik yang memanfaatkan teknologi informasi adalah Lembaga Pendidikan Sekolah Dasar. Dalam dunia pendidikan sudah terdapat banyak aplikasi multimedia pembelajaran baik dalam bentuk aplikasi maupun game edukasi yang dapat membantu daya ingat atau daya tangkap yang baik untuk anak-anak maupun orang dewasa. Pada penelitian ini dibahas mengenai pembuatan Media Pembelajaran berupa Game Edukasi Sejarah Kemerdekaan Indonesia berbasis Android menggunakan Aplikasi Construct 2. Penerapan Media Pembelajaran berbasis game edukasi ini diterapkan di Sekolah Dasar GMIT Kuanino 3 - Kota Kupang. Pengembangan perangkat lunak menggunakan Metode MDLC Multimedia Development Life Cycle. Media sebelum digunakan diuji oleh Ahli Media dan memperoleh hasil $89,67 \%$ Sangat Baik. Dan hasil uji penggunaan oleh siswa SD memperoleh hasil 88.04\% Sangat Baik.
\end{abstract}

Kata Kunci : Game Edukasi, MDLC, Multimedia Development Life Cycle, Construct 2, Android

\section{PENDAHULUAN}

Perkembangan teknologi informasi pada saat ini meningkat dengan pesat. Pemanfaatannya dalam kehidupan masyarakat secara luas juga mengalami peningkatan yang sangat besar. Hal ini juga terjadi pada dunia pendidikan secara luas, Aziz dkk menjelaskan bahwa perkembangan yang besar dalam bidang teknologi informasi berdampak besar terhadap peran lembaga pendidikan. Sehingga lembaga pendidikan pada saat ini berlomba-lomba dalam membelanjakan sumber keuangannya untuk melakukan update terhadap teknologi informasi [1].

Dalam dunia pendidikan sudah terdapat banyak aplikasi multimedia pembelajaran baik dalam bentuk aplikasi maupun game edukasi yang dapat membantu daya ingat atau daya tangkap yang baik untuk anak-anak maupun orang dewasa. Seperti dalam penelitian Amami dkk menghasilkan game edukasi RPG Matematika. Game edukasi RPG matematika ini menceritakan mengenai seorang anak yang diperintahkan oleh ibunya kepasar untuk membeli buah-buahan, dalam perjalanannya terselip sebuah edukasi matematika yaitu pengoperasi bilangan dalam kehidupan sehari-hari. Dari hasil angket respon pengguna didapat bahwa Game edukasi RPG matematika ini menarik, menyenangkan, dan dapat mengedukasi penggunanya [2]. 
Penelitian Rina Nugisari dkk menghasilkan sebuah game edukasi tentang tata surya yang dapat membantu proses pembelajaran pada siswa sekolah dasar. Berdasarkan hasil pengujian usabilitas dengan rata-rata total 66,25 dengan jumlah frekuensi user tertinggi 13 responden pada SUS score 61-80 menunjukkan bahwa game cukup baik untuk membantu proses belajar siswa. Beberapa hasil responden juga menunjukkan bahwa user menyukai game ini sehingga akan dimainkan berkalikali. [3]

Game edukasi sangat menarik untuk dapat dikembangkan dalam menunjang proses pendidikan serta memiliki beberapa keunggulan yang signifikan yaitu memiliki animasi yang mampu menarik perhatian peserta didik agar peserta didik dapat menikmati proses belajar dan juga dapat meningkatkan daya ingat peserta didik untuk mampu menyimpan materi pelajaran dalam waktu yang lebih lama dibandingkan dengan metode pengajaran konvensional.

Dengan berkembangnya teknologi, informasi dan komunikasi maka guru dituntut untuk dapat membuat atau merancang suatu pembelajaran yang efektif, efisien dan yang menyenangkan bagi peserta didik. Dalam hal ini terkhususnya pada mata pelajaran ilmu pengetahuan sosial. Mata pelajaran Ilmu Pengetahuan Sosial (IPS) sangat penting karena didalamnya memuat materi tentang sejarah, geografi dan ilmu sosial lainnya untuk mempersiapkan serta mendidik peserta didik untuk hidup dan memahami dunianya. Indonesia memiliki sejarah penting yang melekat dan tidak dapat hilang dari benak bangsa Indonesia. Bahkan sejarah menjadi mata pelajaran yang harus dipahami bagi peserta didik Indonesia. Sejarah kemerdekaan Indonesia menjadi salah satu bahan ilmu pengetahuan dengan berbagai pelajaran hidup yang perlu diteladani, seperti sikap patriotisme, cinta tanah air, dan rela berkorban dari para pejuang yang gugur.

Salah satu permasalahan dalam dunia pendidikan saat ini yaitu guru belum mampu memanfaatkan media pembelajaran yang menyenangkan untuk peserta didik tertarik dalam proses pembelajaran, sehingga tingkat motivasi belajar peserta didik menjadi rendah terhadap proses pembelajaran.

Berdasarkan hasil pengamatan langsung di SD GMIT Kuanino 3 Kupang pada saat kegiatan pembelajaran mata pelajaran sejarah di kelas $\mathrm{V}$, peserta didik belum mampu menguasai materi sejarah kemerdekaan Indonesia dengan baik, guru tidak menggunakan model pembelajaran yang bervariasi dalam proses pembelajaran berlangsung. Guru masih menggunakan model pembelajaran secara konvensional yaitu guru lebih banyak membaca buku teks tentang materi sejarah kemerdekaan Indonesia, sehingga peserta didik hanya mendengarkan dan mencatat tanpa mampu untuk melakukan sesuatu. Hal ini menyebabkan dalam proses pembelajaran, peserta didik tidak aktif dalam proses pembelajaran, peserta didik cepat bosan, jenuh dan malas untuk belajar.

Berdasarkan permasalahan yang diuraikan di atas, maka peneliti ingin menerapkan Game Edukasi Sejarah Kemerdekaan Indonesia berbasis Android sebagai media pembelajaran yang 
menyenangkan dengan menggunakan aplikasi Construct 2, untuk dapat membantu peserta didik dalam memahami materi dalam proses pembelajaran yang dilakukan oleh guru. Diharapkan dengan game edukasi ini dapat menarik motivasi belajar peserta didik dan dapat meningkatkan hasil belajar peserta didik.

\section{METODE PENELITIAN}

\section{a. Metode Research and Development (R\&D)}

Metode Penelitian yang digunakan dalam penelitian ini adalah metode Research and Development (R\&D). Metode penelitian dan pengembangan atau dalam bahasa Inggrisnya Research and Development adalah metode penelitian yang digunakan untuk menghasilkan produk tertentu, dan menguji keefektifan produk tersebut[4].

\section{b. Metode Pengumpulan Data}

Pada penelitian ini peneliti menggunakan metode pengumpulan data dengan cara melakukan observasi, pembagian angket dan studi pustaka. Pada penelitian ini, observasi dilakukan di SD GMIT Kuanino 3, Jalan Pocoranakan No.6A-Kecamatan Kota Raja untuk mengamati proses pelaksanaan pembelajaran di kelas $\mathrm{V}$ pada Mata Pelajaran Sejarah dengan topik Sejarah Kemerdekaan Indonesia.

Peneliti juga melakukan pembagian angket kepada siswa dan guru. Penulis menggunakan angket untuk memperoleh data dari responden setelah menggunakan produk berupa game edukasi berbasis android pada materi sejarah kemerdekaan Indonesia. Angket yang digunakan dalam penelitian dan pengembangan ini adalah dengan menggunakan skala Likert. Alternatif jawaban dengan skala likert yaitu: sangat baik (SB), baik (B), cukup (C), kurang (K), sangat kurang (SK).

Dalam Studi Pustaka, peneliti mengumpulkan data dan informasi melalui dokumen-dokumen seperti Rencana Pelaksanaan Pembelajaran (RPP), Silabus, dan Daftar Hadir Siswa.

\section{c. Metode Pengembangan Perangkat Lunak}

Pada penelitian ini, peneliti menggunakan Metode MDLC Multimedia Development Life Cycle. Pada Metode MDLC terdapat enam tahapan yaitu: konsep (Concept), perancangan (Desain), pengumpulan bahan (Material Collecting), pembuatan (Assembly), pengujian (Testing), dan distribusi (Distribution), dapat dilihat pada gambar 1.

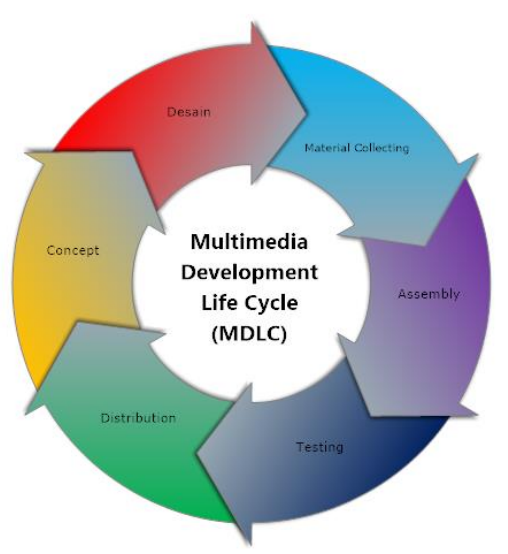

Gambar 1. Metode MDLC - Multimedia Development Life Cycle

\section{HASIL DAN PEMBAHASAN} a. Deskripsi Media Pembelajaran

Media pembelajaran dibuat oleh peneliti yaitu media pembelajaran Game Edukasi Sejarah Kemerdekaan Indonesia 
dengan Aplikasi Construct 2. Media pembelajaran ini diperuntukkan untuk kelas V, SD GMIT Kuanino 3 - Kota Kupang. Dengan pembahasan pada mata pelajaran IPS, materi Sejarah Kemerdekaan Indonesia.

Pada Game Edukasi Sejarah Kemerdekaan Indonesia ini terdapat permainan penyusunan puzzle tokoh pahlawan, quiz, dan juga menampilkan materi Sejarah Kemerdekaan Indonesia dan materi tokoh Sejarah yang memuat audio berisi narasi materi juga teks materi tersebut.

\section{b. Tampilan Produk}

Adapun tampilan media pembelajaran Game Edukasi Sejarah Kemerdekaan Indonesia dengan Aplikasi Construct 2 pada Mata Pelajaran IPS kelas V SD GMIT Kuanino 3, Kota Kupang adalah sebagai berikut :

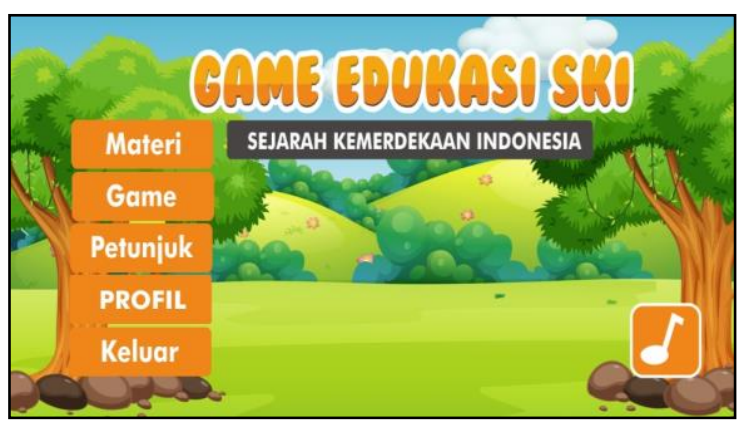

Gambar 2. Halaman Utama - Game Edukasi Sejarah Kemerdekaan Indonesia

Halaman depan media pembelajaran ini menampilkan Judul Game, dan 5 (lima) Menu Utama yaitu Materi, Game, Petunjuk, Profil, dan Exit. Juga terdapat Tombol musik on/off yang berfungsi untuk mengaktifkan dan menonaktifkan musik latar (gambar2).

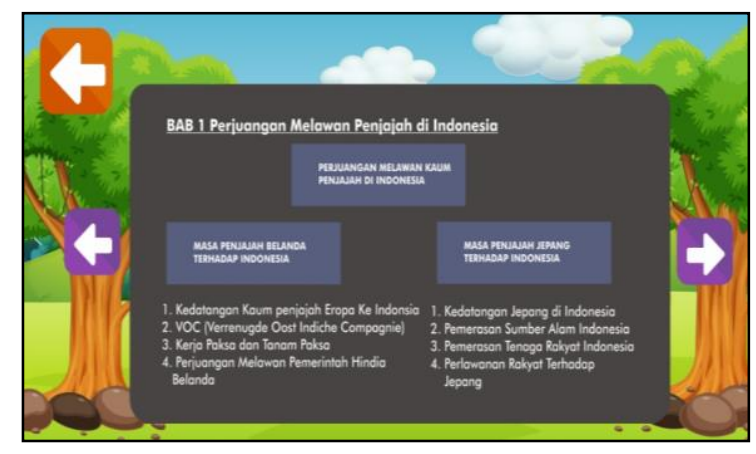

Gambar 3. Halaman Materi Sejarah Kemerdekaan Indonesia

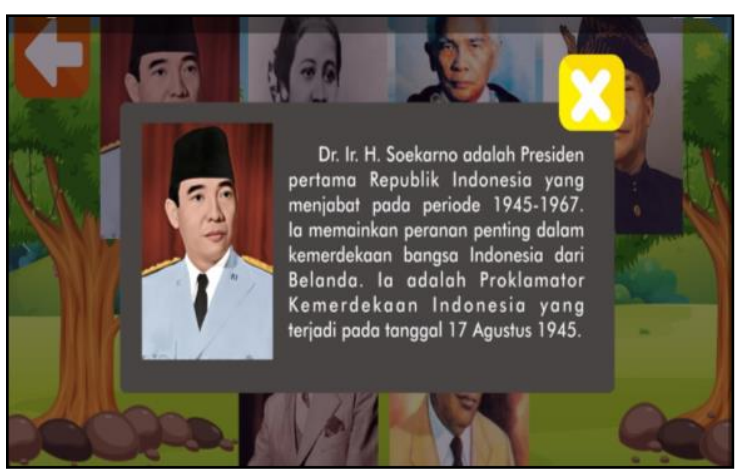

Gambar 4. Halaman Materi Tokoh Sejarah

Materi Sejarah dan materi Tokoh Sejarah tidak hanya menampilkan teks berupa informasi materi tetapi juga terdapat audio narrator yang membacakan materi bagi peserta didik yang mengakses game edukasi ini (gambar 3 dan gambar 4).

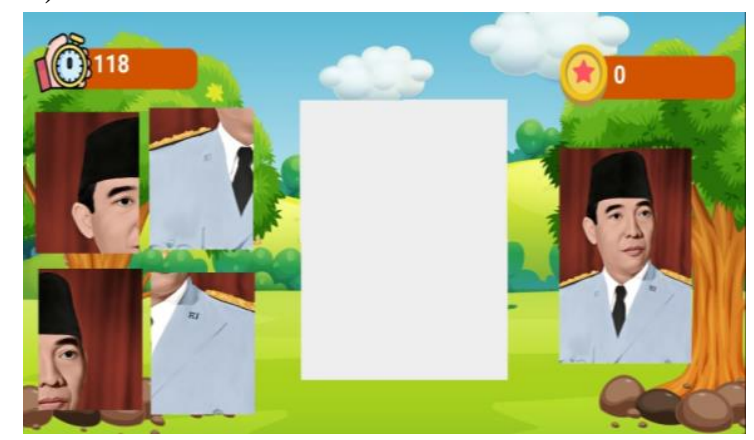

Gambar 5. Halaman Game Puzzle

Dalam halaman game puzzle terdapat potongan - potongan gambar tokoh pahlawan serta timer dan skor. Peserta didik yang mengakses game 
diminta untuk menyusun gambar tokoh pahlawan tersebut, setelah berhasil menyusun maka akan tampil soal tentang nama dari tokoh pahlawan tersebut dan peserta didik harus menjawab dengan benar untuk mendapatkan skor dan kemudian puzzle akan berlanjut ke gambar selanjutnya (gambar 5).

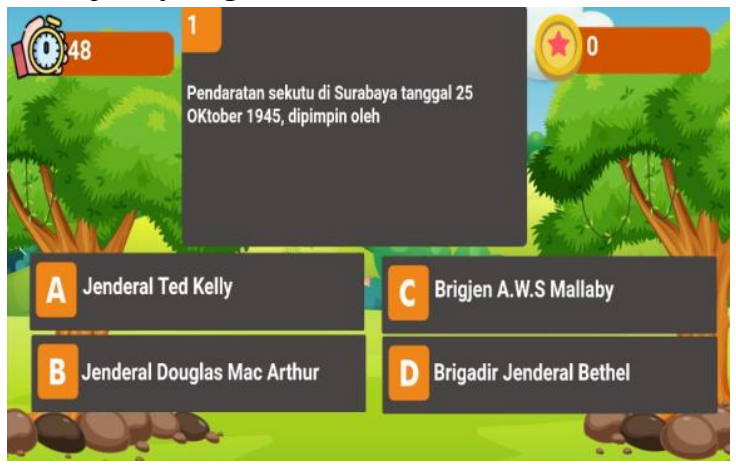

Gambar 6. Halaman Game Quiz

Dalam halaman game quiz terdapat soal pilihan ganda tentang Materi Sejarah Kemerdekaan Indonesia serta timer dan skor. Untuk jawaban yang dijawab dengan benar oleh peserta didik maka skor akan bertambah. Timer, atau waktu akan berjalan mundur saat soal telah tampil pada layar (gambar 6 dan gambar 7).

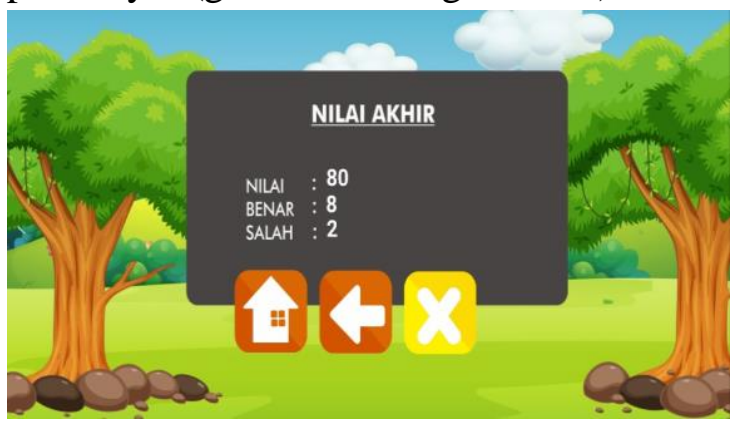

Gambar 7. Halaman Papan Skor Game Quiz

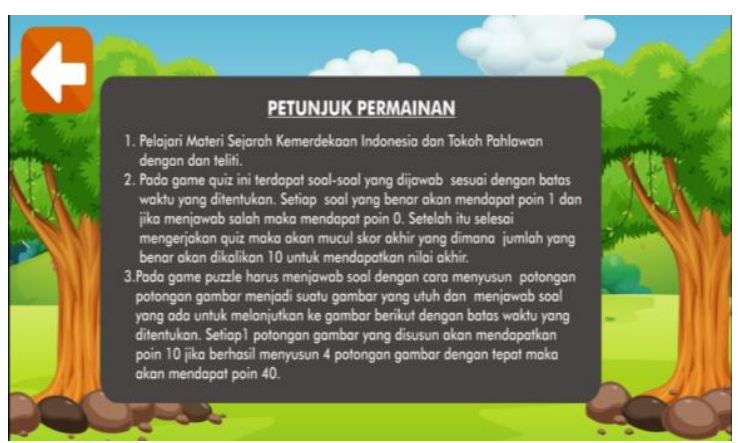

Gambar 8. Halaman Petunjuk

Pada Game Edukasi Sejarah Kemerdekaan Indonesia ini juga menampilan halaman petunjuk penggunaan game dan halaman profil pembuat game (gambar 8 dan gambar 9).

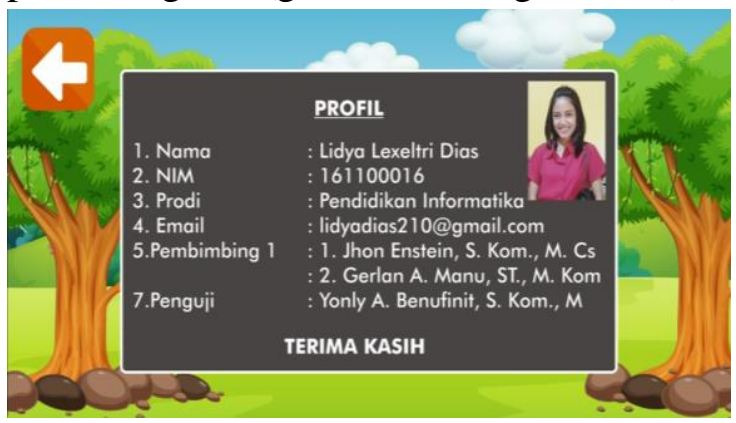

Gambar 9. Halaman Profil

\section{c. Validasi Ahli Media}

Dalam memvalidasi media pembelajaran, peneliti melakukan validasi ahli media. Terdapat 3 ahli media yang melakukan uji coba produk sebelum media digunakan oleh peserta didik dalam hal ini siswa Kelas V SD GMIT Kuanino 3, Kota Kupang.

Hasil ujicoba produk yang dilakukan oleh Ahli Media diisi dalam angket pengujian ahli media. Hasil Angket tersebut dihitung menggunakan rumus [4]:

$$
p=\frac{x}{x i} x 100 \%
$$

$$
\begin{aligned}
& \mathrm{P}=\text { Presentase yang dicari } \\
& \mathrm{X}=\text { Jumlah jawaban }
\end{aligned}
$$


$\mathrm{Xi}=$ Jumlah nilai ideal untuk keseluruhan item

$100 \%=$ Bilangan konstan

Untuk dapat memberikan makna dan pengambilan keputusan pada tingkat ketepatan, kemenarikan, dan keefektifan dapat dipadankan dengan skala tingkat pencapaian sebagai berikut[4] :

Tabel 1. Kualifikasi Kelayakan

\begin{tabular}{ll}
\hline Tingkat Pencapaian & Kualifikasi Kelayakan \\
\hline $\mathbf{8 5}-\mathbf{1 0 0 \%}$ & $\begin{array}{l}\text { Sangat baik, tidak perlu } \\
\text { direvisi }\end{array}$ \\
\hline $\mathbf{7 5 - \mathbf { 8 4 } \%}$ & Baik, tidak perlu \\
& direvisi \\
\hline $\mathbf{6 5}-\mathbf{7 4 \%}$ & Cukup, direvisi \\
\hline $\mathbf{5 5}-\mathbf{6 4 \%}$ & Kurang, direvisi \\
\hline $\mathbf{0 - 5 4 \%}$ & Sangat kurang, direvisi \\
\hline
\end{tabular}

Hasil Pengujian Ahli Media pertama :

$$
\begin{aligned}
p & =\frac{x}{x i} x 100 \% \\
& =72 / 75 \times 100 \\
& =0,96 \times 100 \\
& =96 \%
\end{aligned}
$$

Hasil Pengujian Ahli Media kedua :

$$
\begin{aligned}
p & =\frac{x}{x i} x 100 \% \\
& =70 / 75 \times 100 \\
& =0,93 \times 100 \\
& =93 \%
\end{aligned}
$$

\begin{tabular}{|c|c|c|c|c|}
\hline No. & $\begin{array}{c}\text { Ahli } \\
\text { Media }\end{array}$ & $\begin{array}{c}\text { Perhitu } \\
\text { ngan }\end{array}$ & $\%$ & $\begin{array}{c}\text { Tingkat } \\
\text { Pencapaian }\end{array}$ \\
\hline 1 & $\begin{array}{l}\text { Ahli } \\
\text { Media } \\
\text { Pertama }\end{array}$ & $\begin{array}{l}72 / 75 * \\
100\end{array}$ & $\begin{array}{l}96 \\
\%\end{array}$ & $\begin{array}{l}\text { Sangat Baik, } \\
\text { tidak perlu } \\
\text { direvisi }\end{array}$ \\
\hline 2 & $\begin{array}{l}\text { Ahli } \\
\text { Media } \\
\text { Kedua }\end{array}$ & $\begin{array}{l}70 / 75 * \\
100\end{array}$ & $\begin{array}{l}93 \\
\%\end{array}$ & $\begin{array}{l}\text { Sangat Baik, } \\
\text { tidak perlu } \\
\text { direvisi }\end{array}$ \\
\hline 3 & $\begin{array}{l}\text { Ahli } \\
\text { Media } \\
\text { Ketiga }\end{array}$ & $\begin{array}{l}60 / 75 * \\
100\end{array}$ & $\begin{array}{l}80 \\
\%\end{array}$ & $\begin{array}{l}\text { Baik, tidak } \\
\text { perlu } \\
\text { direvisi }\end{array}$ \\
\hline & \multicolumn{2}{|c|}{ Rata-Rata } & $\begin{array}{l}89,6 \\
7 \%\end{array}$ & $\begin{array}{l}\text { Sangat } \\
\text { Baik, tidak } \\
\text { perlu } \\
\text { direvisi }\end{array}$ \\
\hline
\end{tabular}

Hasil Pengujian Ahli Media ketiga :

$$
\begin{aligned}
p & =\frac{x}{x i} x 100 \% \\
& =60 / 75 \times 100 \\
& =0,8 \times 100
\end{aligned}
$$

$$
=80 \%
$$

Sehingga diperoleh :

Tabel 2. Validasi Ahli Media

menyatakan bahwa Game Edukasi Sejarah Kemerdekaan Indonesia ini Sangat Baik, tidak perlu direvisi.

\section{d. Pengujian Produk}

Setelah hasil validasi ahli media telah diperoleh dan memenuhi kualifikasi kelayakan minimal Baik, maka Media Pembelajaran berupa Game Edukasi Sejarah Kemerdekaan Indonesia ini dapat digunakan oleh peserta didik, dalam hal ini siswa Kelas V SD GMIT Kuanino 3, Kota Kupang.

Dalam penelitian ini game edukasi Sejarah Kemerdekaan Indonesia ini 
kemudian digunakan oleh 21 peserta didik.

Setelah menggunakan game edukasi ini, peserta didik mengisi kuesioner/angket penggunaan game.

Berdasarkan hasil angket penggunaan game edukasi oleh siswa diatas maka diperoleh rata-rata persentase kelayakan game edukasi oleh siswa sebesar 88,04\%, dengan tingkat pencapaian kelayakan Sangat Baik (tabel $3)$.

Tabel 3. Perhitungan Hasil Angket Penggunaan Game Edukasi oleh Siswa

\begin{tabular}{|c|c|c|c|c|}
\hline $\begin{array}{l}\mathbf{N} \\
\mathbf{o}\end{array}$ & $\begin{array}{l}\text { Nama } \\
\text { Siswa }\end{array}$ & $\begin{array}{c}\text { Perhitun } \\
\text { g } \\
\text { an }\end{array}$ & $\%$ & $\begin{array}{c}\text { Tingkat } \\
\text { Pencapaia } \\
\text { n }\end{array}$ \\
\hline 1 & $\begin{array}{c}\text { Maurel S. } \\
\text { Putri } \\
\text { Baba }\end{array}$ & $\begin{array}{c}74 / 75 * \\
100\end{array}$ & $99 \%$ & $\begin{array}{c}\text { Sangat } \\
\text { Baik, tidak } \\
\text { perlu } \\
\text { direvisi }\end{array}$ \\
\hline 2 & $\begin{array}{l}\text { Magdalen } \\
\text { a S. Adu }\end{array}$ & $\begin{array}{c}70 / 75 * \\
100\end{array}$ & $93 \%$ & $\begin{array}{c}\text { Sangat } \\
\text { Baik, tidak } \\
\text { perlu } \\
\text { direvisi }\end{array}$ \\
\hline 3 & $\begin{array}{l}\text { Orga D. } \\
\text { Oematan }\end{array}$ & $\begin{array}{c}70 / 75 * \\
100\end{array}$ & $93 \%$ & $\begin{array}{c}\text { Sangat } \\
\text { Baik, tidak } \\
\text { perlu } \\
\text { direvisi }\end{array}$ \\
\hline 4 & $\begin{array}{c}\text { Fitri } \\
\text { Lenama }\end{array}$ & $\begin{array}{c}70 / 75 * \\
100\end{array}$ & $93 \%$ & $\begin{array}{c}\text { Sangat } \\
\text { Baik, tidak } \\
\text { perlu } \\
\text { direvisi }\end{array}$ \\
\hline 5 & $\begin{array}{c}\text { Forlan F. } \\
\text { Adu }\end{array}$ & $\begin{array}{c}63 / 75 * \\
100\end{array}$ & $84 \%$ & $\begin{array}{c}\text { Baik, tidak } \\
\text { perlu } \\
\text { direvisi }\end{array}$ \\
\hline 6 & Fernando & $62 / 75 *$ & $83 \%$ & Baik, tidak \\
\hline
\end{tabular}

\begin{tabular}{|c|c|c|c|c|}
\hline & $\begin{array}{l}\text { R. C. } \\
\text { Amabi }\end{array}$ & 100 & & $\begin{array}{c}\text { perlu } \\
\text { direvisi }\end{array}$ \\
\hline 7 & $\begin{array}{c}\text { Rizky A. } \\
\text { Pollo }\end{array}$ & $\begin{array}{c}62 / 75 * \\
100\end{array}$ & $83 \%$ & $\begin{array}{c}\text { Baik, tidak } \\
\text { perlu } \\
\text { direvisi }\end{array}$ \\
\hline 8 & $\begin{array}{l}\text { Jems } \\
\text { Mbau }\end{array}$ & $\begin{array}{c}65 / 75 * \\
100\end{array}$ & $87 \%$ & $\begin{array}{c}\text { Sangat } \\
\text { Baik, tidak } \\
\text { perlu } \\
\text { direvisi }\end{array}$ \\
\hline 9 & $\begin{array}{c}\text { Saskia M. } \\
\text { Ibrahim }\end{array}$ & $\begin{array}{c}65 / 75 * \\
100\end{array}$ & $87 \%$ & $\begin{array}{c}\text { Sangat } \\
\text { Baik, tidak } \\
\text { perlu } \\
\text { direvisi }\end{array}$ \\
\hline 10 & $\begin{array}{c}\text { Justen E. } \\
\text { Mbau }\end{array}$ & $\begin{array}{c}63 / 75 * \\
100\end{array}$ & $84 \%$ & $\begin{array}{c}\text { Baik, tidak } \\
\text { perlu } \\
\text { direvisi }\end{array}$ \\
\hline 11 & $\begin{array}{c}\text { Azarya N. } \\
\text { Deta }\end{array}$ & $\begin{array}{c}62 / 75 * \\
100\end{array}$ & $83 \%$ & $\begin{array}{c}\text { Baik, tidak } \\
\text { perlu } \\
\text { direvisi }\end{array}$ \\
\hline 12 & $\begin{array}{c}\text { Marco A. } \\
\text { Kofi }\end{array}$ & $\begin{array}{c}65 / 75 * \\
100\end{array}$ & $87 \%$ & $\begin{array}{c}\text { Sangat } \\
\text { Baik, tidak } \\
\text { perlu } \\
\text { direvisi }\end{array}$ \\
\hline 13 & $\begin{array}{l}\text { Gilbert D. } \\
\text { I. Saleh } \\
\text { Adu }\end{array}$ & $\begin{array}{c}70 / 75 * \\
100\end{array}$ & $93 \%$ & $\begin{array}{c}\text { Sangat } \\
\text { Baik, tidak } \\
\text { perlu } \\
\text { direvisi }\end{array}$ \\
\hline 14 & $\begin{array}{c}\text { Jeaneth J. } \\
\text { Dumanau } \\
\text { w }\end{array}$ & $\begin{array}{c}69 / 75 * \\
100\end{array}$ & $92 \%$ & $\begin{array}{c}\text { Sangat } \\
\text { Baik, tidak } \\
\text { perlu } \\
\text { direvisi }\end{array}$ \\
\hline 15 & $\begin{array}{c}\text { Elisya A. } \\
\text { Buthe }\end{array}$ & $\begin{array}{c}65 / 75 * \\
100\end{array}$ & $87 \%$ & $\begin{array}{c}\text { Sangat } \\
\text { Baik, tidak } \\
\text { perlu } \\
\text { direvisi }\end{array}$ \\
\hline 16 & $\begin{array}{c}\text { Margaret } \\
\text { ha C. } \\
\text { Haumetan }\end{array}$ & $\begin{array}{c}62 / 75 * \\
100\end{array}$ & $83 \%$ & $\begin{array}{c}\text { Baik, tidak } \\
\text { perlu } \\
\text { direvisi }\end{array}$ \\
\hline
\end{tabular}




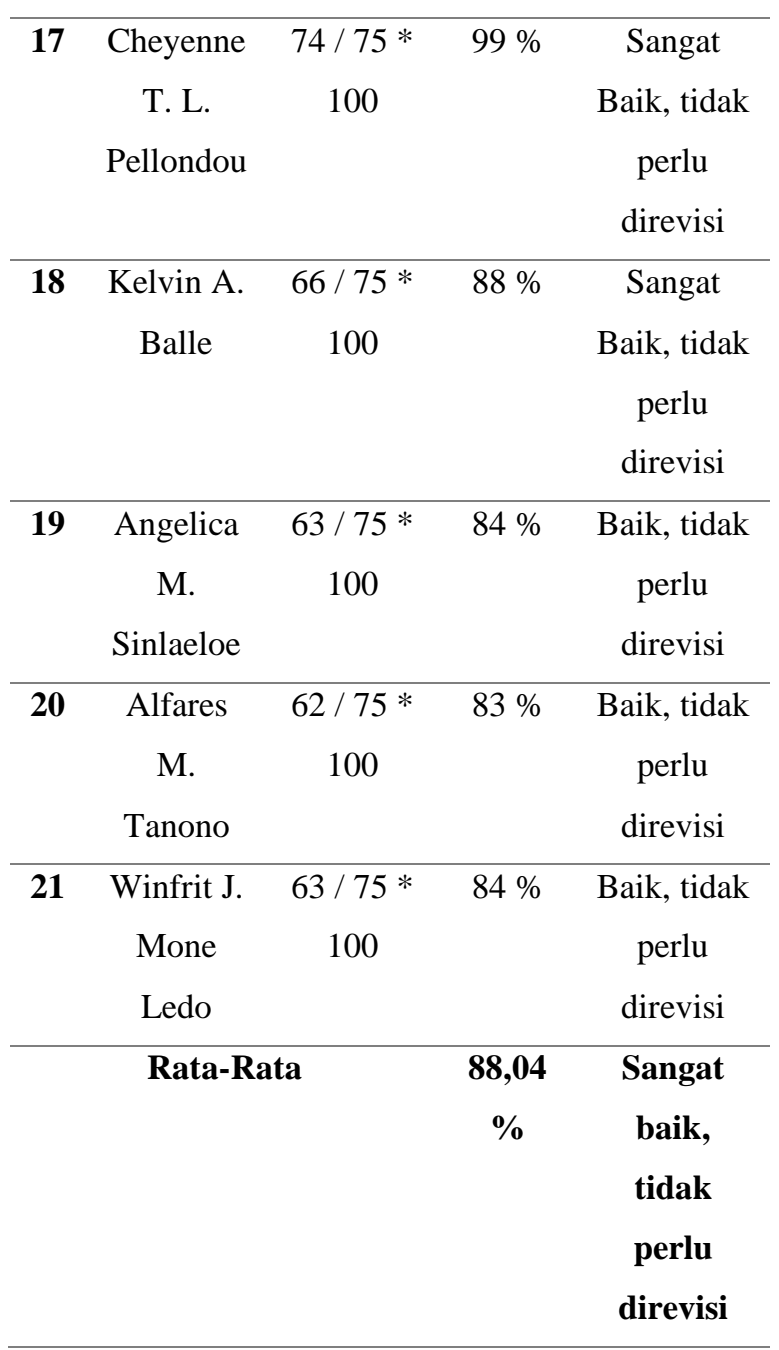

\section{KESIMPULAN}

Penelitian ini menghasilkan Media Pembelajaran berupa Game Edukasi Sejarah Kemerdekaan Indonesia berbasis Android menggunakan Aplikasi Construct 2. Metode Pengembangan Perangkat Lunaknya menggunakan Metode MDLC yang terdiri dari enam tahap, yaitu Concept, Design, Material Collecting, Assembly, Testing, dan Distribution.

Berdasarkan hasil penerapan Game Edukasi Sejarah Kemerdekaan Indonesia berbasis Android di kelas V SD GMIT
Kuanino 3, menunjukkan bahwa Game Edukasi layak untuk digunakan dengan nilai akhir $88.04 \%$ dan tingkat pencapaian sangat baik sebagai Media Pembelajaran IPS, Khususnya Materi Sejarah Kemerdekaan Indonesia kelas V di SD GMIT Kuanino 3.

\section{DAFTAR PUSTAKA}

[1] Aziz, Tahir, M. . Khan, dan R. Singh, "Effects of Information Technology Usage on Student Learning: An Empirical Study in the United States," Int. J. Manag., vol. 27 , no. 2,2010

[2] S. Amami Pramuditya, M. S. Noto, dan D. Syaefullah, "GAME EDUKASI RPG MATEMATIKA," Eduma Math. Educ. Learn. Teach., vol. 6 , no. 1, 2017, doi:

10.24235/eduma.v6i1.1701.

[3] R. Nuqisari dan E. Sudarmilah, "Pembuatan Game Edukasi Tata Surya Dengan Construct 2 Berbasis Android," Emit. J. Tek. Elektro, vol. 19, no. 2, 2019, doi:

10.23917/emitor.v19i2.7987.

[4] Sugiyono, Metode Penelitian Kuantitatif, Kualitatif dan $R \& D$. Bandung: Alfabeta, 2017. 